\title{
ANALISIS STOCK SPLIT TERHADAP HARGA SAHAM DAN VOLUME PERDAGANGAN SAHAM INDEK LQ-45 PERIODE 2010 - 2016
}

\author{
Ibnu Khajar \\ Universitas Islam Sultan Agung (Unissula) \\ Jl. Raya Kaligawe, Km4, Semarang - Indonesia.
}

\begin{abstract}
Stock split is not a new issue in Indonesia Stock exchange. There are many controversies are found in the research results about the impact of the corporation action on the company value and stock trading volume. This study aims to analyze the impact of stock split on stock price and stock trading volume. Four companies incorporated in LQ-45 of Indonesia Stock Exchange become the sample of this research. One sample t-test and paired sample t-test are used as the statistical analysis method. The result shows that corporation action of stock split positively impact on stock price, but negatively impact on stock trading volume.
\end{abstract}

Key Words: Stock Split, Stock Reverse, One Sample T-Test, Paired Sample T-Test.

\section{PENDAHULUAN}

Pemecahan saham bukan masalah yang baru untuk Bursa Efek Indonesia, terbukti sejak periode 2010 hingga saat ini tidak kurang dari 66 emiten telah melakukan pemecahan saham baik stock split (pemecahan saham) ataupun stock reverse (penggabungan saham). Banyak investor memandang pemecahan saham merupakan sinyal semakin baiknya kinerja perusahaan dan sebaliknya penggabungan saham sinyal negatip pertanda semakin buruknya kinerja perusahaan. Data Bursa Efek Indonesia menunjukkan dari 66 emiten yang melakukan corporate action tersebut hanya sekitar $18 \%$ yang melakukan penggabungan saham sisanya adalah melakukan pemecahan saham, sebagaimana Tabel 1.

Tabel 1. Corporate Action Stock Split dan Reverse 2010-2016

\begin{tabular}{cccccccc}
\hline $\begin{array}{c}\text { Corporate } \\
\text { Action }\end{array}$ & $\mathbf{2 0 1 0}$ & $\mathbf{2 0 1 1}$ & $\mathbf{2 0 1 2}$ & $\mathbf{2 0 1 3}$ & $\mathbf{2 0 1 4}$ & $\mathbf{2 0 1 5}$ & $\mathbf{2 0 1 6}$ \\
\hline $\begin{array}{c}\text { Stock Split } \\
\text { Reverse }\end{array}$ & 6 & 11 & 16 & 11 & 5 & 14 & 3 \\
$\begin{array}{l}\text { Stock } \\
\text { Sumber: PT Kustodion Sentral Efek Indonesia }\end{array}$ & 2 & 3 & 1 & 2 & 2 & - \\
\hline
\end{tabular}

Keyakinan investor bahwa pemecahan saham merupakan sinyal baik tidak sepenuhnya benar

Korespondensi dengan Penulis:

Ibnu Khajar, HP +6281326568880

e-mail: didijon58@yahoo.co.id 


\section{Jurnal Keuangan dan Perbankan | KEUANGAN}

Vol. 20, No.3, September 2016: 395- 406

beberapa hasil penelitian ada yang mendukung sekaligus ada yang kontra. Mishra (2006), Bechmann dan Raaballe (2007) dan Cakraborty (2012) menganggap bahwa Kebijakan pemecahan saham hanyalah pemercantik (lipstick) saja dan tidak mempengaruhi kekayaan pemegang saham, jumlah lembar saham menjadi semakin banyak akan tetapi dengan harga saham yang lebih murah. Akan tetapi bagaimana harga saham pada beberapa periode kedepan pasca aksi merupakan peristiwa yang menarik untuk diteliti. Jika harga saham beberapa periode kedepan pasca aksi korporasi berakibat pada naiknya harga saham maka aksi tersebut mendatangkan manfaat pada para pemegang saham karena kekayaan meningkat pasca aksi korporasi tersebut, akan tetapi jika harga saham justru menurun maka aksi tersebut akan menurunkan kekayaan dan menimbulkan kerugian. Kurniawati (2003) melakukan riset terkait masalah pemecahan saham mencatat mencatat bahwa terdapat abnormal negatip disekitar pengumuman pemecahan saham, artinya pasca aksi harga saham justru menurun. Berbeda halnya dengan Waweru dan Mwendwa (2012) mencatat bahwa dari 10 perusahaan setelah melakukan pemecahan saham di Nairobi Stock Exchange (NSE) 5 perusahaan harga sahamnya naik dan 5 perusahaan pula harga sahamnya turun. Metha, Yadav dan Jain (2011) hasil penelitiannya mencatat bahwa mayoritas responden tidak percaya pemecahan saham memberikan sinyal positip tentang prospek kedepan perusahaan. Pooja (2013) mencatat perusahaan yang melakukan pemecahan saham di bursa efek India tidak berpengaruh terhadap harga saham. Ford, H. Nguyen dan T. Nguyen (2012) menyatakan bahwa pasca pemecahan saham harga saham justru mengalami penurunan.

Jika dilihat dari likuiditas pasca pemecahan saham banyak hasil penelitian mencatat adanya kenaikan secara signifikan, sebagaimana dalam Mishra (2006), Cakraborty (2012), Kurniawati (2003), Waweru dan Mwendwa (2012), Metha, Yadav dan Jain (2011), Pooja (2013) serta Ford, H.Nguyen, dan T.Nguyen (2012). Berdasarkan research gap tersebut, maka urgen dan menarik untuk diteliti bagaimana dampak aksi korporasi pemecahan saham yang terjadi di Bursa Efek Indonesia (BEI) terhadap harga saham dan volume perdagangan saham.

\section{Tujuan Penelitian}

Pemecahan saham merupakan corporate action yang dilakukan oleh perusahaan-perusahaan yang telah go-publik baik di Indonsia maupun di Bursa - Bursa negara lain. Permasalahan dalam penelitian ini adalah bagaimana harga saham dan volume perdagangan saham sebelum dan sesudah pemecahan saham. Sehingga tujuan dalam penelitian ini adalah ingin mengetahui dan menganalisis haraga saham dan volume perdagangan saham pada perusahaan-perusahaan yang melakukan corporate action stock split. Hasil kahir dari penelitian ini diharapkan bermanfaat untuk menambah referensi maupun informasi bagi investor di pasar modal dalam pengambilan keputusan mereke dalam investasi saham. Selain itu juga diharapkan dapat menambah wawasan dan referensi bagi mahasiswa khususnya Mahasiswa Fakultas Ekonomi mata kuliah Manajemen Keuangan pada umumnya dan manajemen Investasi portfolio dan pasar modal khususnya.

\section{HIPOTESIS}

\section{Pemecahan dan Penggabungan Saham}

Terdapat dua jenis pemecahan saham yaitu forward split dan reverse split (Yan dan Junbo,2012). Bechmann dan Raaball (2007) menyatakan forward split menjadikan satu lembar saham lama dipecah kedalam sejumlah lembar saham baru dengan menurunkan nilai nominal saham, dan total modal saham tidak berubah. Terkait dengan forward split, Jones (2007:41) menyatakan bahwa stock split melibatkan penerbitan jumlah lembar saham yang lebih besar proporsional dengan lembar saham 
yang beredar. Dengan stock split, nilai buku dan nilai nominal (par) berubah, sebagai contoh masingmasing nilai akan dipotong setengah jika rasio split adalah 1:2. Hwang et al (2012) menyatakan reverse splits adalah peristiwa yang tidak biasa dimana perusahaan mensubstitusi beberapa lembar saham dengan satu lembar saham tanpa perubahan apapun dalam total kapitalisasi modal saham.

Beberapa alasan mengapa perusahaan melakukan pemecahan saham diantaranya Forward split memecah satu lembar saham menjadi beberapa lembar sehingga mengakibatkan lebih banyak lembar saham dibandingkan sebelumnya, tetapi harga perlembar saham menjadi lebih murah. Sedangkan reverse split adalah menggabungkan/ mengkombinasi beberapa lembar saham menjadi satu lembar saham, akibatnya harga perlembar saham meningkat dan saham beredar menurun.

\section{Harga Saham}

Saham merupakan bukti kepemelikan atas suatu perusahaan. Siapapun yang memiliki lembar saham dari suatu perusahaan yang telah go public, baik diperoleh melalui pembelian saham di Bursa Efek ataupun diperoleh selain itu, misalnya melalui bonus yang diterimanya dari perusahaan berupa lembar saham, maka orang tersebut merupakan pemegang saham atau pemilik perusahaan sesuai dengan jumlah lembar saham yang dimiliki. Semakin banyak jumlah lembar saham yang dimiliki semakin besar prosentase kepemilikan atas perusahaan dimaksud.

Saham mempunyai beberapa jenis harga, harga nominal dan harga pasar. Perusahaan yang sudah go public mempunyai harga nominal dan harga di pasar baik di pasar perdana ataupun di pasar sekunder. Terkecuali untuk harga saham di pasar sekunder, harga nominal dan harga pasar perdana bersifat statis. Dalam perkembangannya harga nominal juga akan berubah manakala perusahaan (emiten) melakukan aksi korporasi misalnya pemecahan saham (stock split) atau sebaliknya penggabungan saham (stock reverse).
Di dalam banyak buku leteratur keuangan disebutkan bahwa perusahaan didirikan dalam rangka mendapatkan laba (keuntungan) dan meningkatkan kekayaan pemilik. Jika perusahaan beroperasional dengan untung maka secara kumulatip semakin panjang periode waktu berjalannya perusahaan maka akan semakin besar pula kekayaan pemilik perusahaan. Berapa naiknya kekayaan pemilik dapat dihitung dari berapa besar keuntungan yang diperoleh baik dalam bentuk uang tunai maupun dalam bentuk asset lainnya. Khusus untuk perusahaan yang sudah go public, berapa besar kekayaan pemilik perusahaan analog dengan berapa kekayaan para pemegang saham relatip mudah untuk dihitung. Karena perusahaan yang sudah go public mempunyai harga pasar saham (pasar sekunder), berapa kekayaannya dengan sederhana tinggal dihitung berapa lembar saham yang dimiliki dikalikan dengan harga per lembar sahamnya di pasar. Bagaimana kekayaan mereka bisa meningkat, hal ini akan pararel dengan kinerja perusahaan, tingkat keuntungan perusahaan. Jika perusahaan di mana mereka memiliki sahamnya memperoleh keuntungan maka harga pasar sahamnya juga akan meningkat. Meskipun jumlah lembar saham yang dimiliki tetap akan tetapi harga pasar sahamnya naik maka kekayaan investor pemegang saham tersebut juga meningkat. Meningkatnya kekayaan pemilik analog dengan telah tercapainya tujuan perusahaan. Sehingga khusus untuk perusahaan yang sudah go public baik buruknya kinerja perusahaan dapat diamati dari pergerakan harga saham. Harga saham mengalami naik dan turun sesuai untung ruginya operasional perusahaan.

Mengapa harga saham naik dan turun banyak factor yang mempengaruhinya dan secara garis besar dikelompokkan menjadi dua yaitu factor internal (mikro) maupun eksternal (makro). Internal tercermin dalam keadaan perusahaan, bagaimana penjualan dan pertumbuhan penjualan, bagaimana efisiensi biaya operasional perusahaan baik yang bersifat variable ataupun bersifat tetap apa- 


\section{Jurnal Keuangan dan Perbankan | KEUANGAN}

Vol. 20, No.3, September 2016: 395- 406

kah semakin efisien atau tidak, bagaimana tingkat keuntungan perusahaan. Sedangkan eksternal perusahaan biasanya tidak dapat dikendalikan perusahaan, seperti tingkat bunga perbankan, harga BBM, listrik, keadaan social politik dan hokum. Harga saham perusahaan akan berfluktuasi jika factor-faktor baik internal maupun eksternal mengalami perubahan.

\section{Volume Perdagangan Saham}

Volume perdagangan saham dapat dijadikan salah satu indicator kondisi bursa tersebut apakah ramai atau sepi, semakin besar volume perdagangan semakin ramai bursa artinya semakin banyak lembar saham yang ditransaksikan. Volume perdagangan saham tercatat baik dalam jumlah lembar saham maupun nilai rupiah saham. Misalnya tanggal 27-01-2016 nilai perdagangan saham harian BEI mencapai 5,4 milyar lembar saham atau analog dengan 5,3 Trilyun rupiah (Kontan, 27-01-2016). Semakin banyak investor yang menjual atau membeli saham maka akan semakin tinggi nilai perdagangan saham.

Terdapat beberapa rasio yang digunakan untuk mengukur volume perdagangan saham yaitu TVA (Trade Volume Activity) merupakan rasio antara jumlah saham yang diperdagangkan dengan jumlah saham beredar. Semakin besar nilai TVA maka bisa dinterprestasikan semakin banyak volume saham yang diperdagangkan. Joshipura (2009) menggunakan ratio volume dimana jika nilainya satu atau mendakati satu maka dikatakan volume perdagangan saham adalah normal, akan tetapi jika nilai rasio tidak sama dengan satu dikatakan volume perdagangan saham tidak normal. Kaitanya dengan aksi korporasi dalam pemecahan saham, nanti akan dikaji bagaimana rasio volume perdagangan saham dengan adanya peristiwa pemecahan saham.

\section{Signalling Hypothesis}

Informasi yang ada dipihak manajemen dengan informasi yang diterima investor adalah ber- beda (asimetri informasi), keadaan ini adalah sangat wajar karena pihak internal setiap hari berhadapan langsung dengan keadaan fundamental perusahaan dengan juga secara langsung menjalankan perusahaan. Oleh karena itu ketika perusahaan mengadakan aksi korporasi pemecahan saham dapat dipandang sebagai sinyal bahwa perusahaan mempunyai kinerja yang lebih baik atau minimal mempunyai potensi peningkatan kinerja perusahaan pada masa mendatang. Jika harga saham perusahaan sudah relatip mahal, meskipun kinerja perusahaan meningkat maka relatip tidak dapat mendongkrak harga saham meningkat secara signifikan, diantaranya karena investor tidak mampu membeli karena harga sudah mahal begitu juga akses investor tidak banyak karena yang mampu membeli saham dengan harga yang relatip tinggi tidak banyak khususnya pada kelompok investor menengah kebawah.

Menurut hipotesis signaling manajer dapat menggunkan distribusi saham untuk sinyal berita baik (good news) atau ekspektasi optimistis untuk para investor di pasar modal. Sebagai pihak internal (insider) perusahaan para manajer biasanya mempunyai estimasi terkait prospek perusahaan yang lebih baik dibanding dengan pihak luar (outsider). Oleh karena itu manajer dapat menyampaikan informasi internal mereka kepada investor melalui keputusan keuangan (Powell, Phillips dan Baker, 1995).

Pemecahan Saham, Nilai Perusahaan dan Volume Perdagngan Saham

Aksi korporasi pemecahan saham dianggap sebagi sinyal baik sehingga dapat mempengaruhi harga saham dan akhirnya nilai perusahaan. Jadi kalau perusahaan memecah saham berarti dianggap perusahaan mempunyai kinerja yang lebih baik sehingga pasca pemecahan saham harga saham akan naik dan pada akhirnya nilai perusahaan juga akan naik. Lakonishok and Lev (1987) menyatakan bahwa rata-rata pertumbuhan pendapatan (earnings) periode sebelum pemecahan saham adalah lebih tinggi dibanding dengan perusahaan 
yan tidak melakukan pemecahan saham, begitu juga pasca pemecahan saham tetap lebih tinggi.

Pasca pemecahan saham harga saham dengan nilai nominal baru yang kecil dibandingkan sebelumnya secara langsung berpengaruh terhadap harga jual saham per lembar saham menjadi lebih murah. Konsekwensinya dengan harga saham yang lebih murah maka lebih banyak investor yang mampu membeli saham tersebut sehingga volume perdagangan akan meningkat.

Terdapat beberapa research sebelumnya terkait masalah aksi korporasi terhadap nilai perusahaan baik yang mendukung ataupun yang bertentangan. Pooja (2013) menyebutkan bahwa aksi korporasi pemecahan saham tidak berpengaruh pada harga saham dan nilai perusahaan tetapi berpengaruh terhadap volume perdagangan saham. Cakrabroty (2012) menyebutkan dalam penelitiannya bahwa aksi korporasi pemecahan saham mengahasilkan return positip pada hari pemecahan saham. Mishra (2006) dalam penelitiannya menyatakan bahwa aksi korporasi pemecahan saham berpengaruh negatip terhadap harga saham tetapi berpengaruh positip terhadap volume perdagangan saham. Fama, Fisher, Jensen, and Roll (1969) menemukan dalam penelitiannya bahwa dengan menggunakan sampel sebanyak 60 perusahaan dan periode waktu 60 bulan ditemukan bukti empiris sebelum pemecahan saham abnormal return positip tetapi pasca pemecahan saham tidak terdapat abnormal return. Berdasarkan kajian teoritis tersebut maka terdapat dua hipotesis penelitian:

1. Terdapat abnormal return di sekitar pengumuman pemecahan saham (stock split).

2. Terdapat perbedaan volume perdagangan saham sebelum dan sesudah pengumuman pemecahan saham (stock split).

\section{METODE}

\section{Jenis Penelitian}

Penelitian ini menggunakan metodologi studi peristiwa (event study). Event study umumnya digunakan untuk mengetahui pengaruh suatu peristiwa terhadap harga suatu sekuritas. Peristiwa bisa dalam bentuk pengumuman/ informasi yang dikeluarkan atau diterbitkan oleh perusahaan (emiten) yang Go-Publik, misalnya pengumuman laba, dividen, stock split dan right issue. Penelitian ini akan mengkaji pengaruh stock split terhadap harga dan volume perdagangan saham. Reaksi pasar dalam bentuk perubahan harga saham dapat diukur dengan menggunakan return atau abnormal return yang terjadi di seputar hari pengumuman stock split.

Secara umum metodologi dalam penelitian studi peristiwa mengikuti prosedur sebagai berikut: (1) mengumpulkan sampel perusahaan yang mempunyai suatu peritiwa yang ingin diteliti, (2) menentukan dengan tepat hari atau tanggal cum date (tanggal terakhir saham diperdagangkan dengan nilai nominal lama pengumuman dan ditetapkan sebagai hari 0, (3) menentukan periode penelitian atau event window sebanyak 11 hari, 5 hari sebelum pengumuman corporate action dan 5 hari seseduah cum date, (4) untuk setiap sampel perusahaan dihitung return saham dalam periode harian (5) menghitung abnormal return (mean adjusted model) pada setiap periode di periode jendela untuk seluruh emiten yang menjadi sampel penelitian dari return yang sudah didapatkan untuk tiap perusahaan, (6) menguji secara statistic abnormal return signifikan atau tidak.

\section{Populasi dan Sampel}

Populasi yang digunakan dalam penelitian ini adalah semua perusahaan yang terdaftar di Bursa Efek Jakarta (BEJ) yang masuk dalam daftar saham Indek LQ45 dan telah melakukan stock split pada tahun 2010 sampai dengan tahun 2016. Sampel dipilih berdasarkan kriteria tertentu (purposive sampling) sesuai dengan rencana penelitian. Kriteria pemilihan sampel adalah:

1. Tanggal pengumuman peristiwa pemecahan saham serta Cume Date dapat diketahui. 


\section{Jurnal Keuangan dan Perbankan | KEUANGAN}

Vol. 20, No.3, September 2016: 395- 406

2. Perusahaan yang dipilih tidak melakukan company action lain kecuali melakukan pemecahan saham (stock split) pada event window disekitar hari pengumuman. Alasan penggunaan kriteria tersebut adalah untuk menghindari bias pada harga saham yang disebabkan oleh company action tersebut. Setelah dilakukan seleksi, perusahaan yang memenuhi kriteria tersebut berjumlah 8 perusahaan.

3. Harga saham disekitar pengumuman peristiwa dapat diperoleh

4. Volume perdagangan disekitar pengumuman peristiwa dapat diperoleh

Berdasarkan kriteria pemilihan sampel di atas, diperoleh sampel sebanyak 4 Emiten, yaitu PT Telkom (TLKM), PT Kalbe Farma (KLBF), PT Astra Internasional Indonesia (ASII) dan PT Bank Rakyat IndonesiaI).

\section{Data dan Sumber Data}

Penelitian ini menggunakan data sekunder. Daftar perusahaan yang melakukan stock split baik tanggal pengumuman maupun cum date diperoleh dari Harian bisnis Indonesia dan PT Kustodion Sentral Efek Indonesia (PT KSEI). Sedangkan harga saham periode harian diperoleh dari Yahoo Finance.

\section{Derinisi Operasional Variabel}

Untuk mengetahui pengaruh pengumuman stock split terhadap kemakmuran pemegang saham digunakan variabel sebagai berikut:

1. Hari tanggal cum-date ditetapkan sebagai periode nol $(t=0)$ dalam periode jendela yaitu hari tanggal terakhir saham diperdagangkan dengan nilai nominal lama.

2. Lima hari setelah peristiwa yaitu periode 5 hari setelah periode $\mathrm{t}=0$ (cum-date).

3. Lima hari sebelum peristiwa ditetapkan periode lima harisebelum tanggal pengumuman peristiwa.
4. Return saham, yaitu harga penutupan pada hari tertentu dikurangi dengan harga penutupan hari sebelumnya, dibagi dengan harga penutupan hari sebelumnya.

5. Abnormal return merupakan selisih antara return riil pada pada periode jendela dikurangi dengan return yang diharapkan/biasanya (meanadjusted model).

\section{Model Analisis Data}

1. Model perhitungan return saham individu

$$
R_{i}=\frac{P_{i . t}-P_{i . t-1}}{P_{i . t-1}}
$$

Dimana:

R i.t = return saham $\mathrm{i}$ pada hari ke-t (hari ini)

P i.t-1 = harga saham i pada hari ke t-l (hari sebelumnya)

2. Model perhitungan abnormal return mean adjusted model

$\mathrm{RTN}_{\mathrm{i}, \mathrm{t}}=\mathrm{R}_{\mathrm{i}, \mathrm{t}}-\Sigma\left[\mathrm{R}_{\mathrm{i}, \mathrm{t}}\right]$

Dimana:

$$
\begin{aligned}
\mathrm{RTN}_{\mathrm{i}, \mathrm{t}}= & \text { abnormal return sekuritas ke-i pada } \\
& \text { periode peristiwa ke-t. } \\
\mathrm{E}\left[\mathrm{R}_{\mathrm{i}, \mathrm{t}}\right]= & \Sigma \mathrm{R}_{\mathrm{i}, \mathrm{j}} / \mathrm{T} \text {, return ekspektasi sekuritas } \\
& \text { ke-i pada periode peristiwa ke-t. } \\
\mathrm{R}_{\mathrm{i}, \mathrm{j}} \quad & \begin{aligned}
\text { return realisasi sekuritas ke-I pada } \\
\text { periode estimasi ke- } \mathrm{j}
\end{aligned} \\
\mathrm{T} \quad & \text { lamanya periode estimasi }
\end{aligned}
$$

3. Model pengujian hipotesis

1. Paired Sampel t-test

Alat uji statistic ini digunakan untuk mengetahui ada tidaknya perbedaan Trade Volume Activity (TVA) sebelum dan sesudah aksi korporasi dalam hal ini pemecahan saham (stock split). Rumusan hipotesisi yang diajukan: 
$H_{o}: \mu_{1}=\mu_{2}$, tidak terdapat perbedaan TVA sebelum dan sesudah aksi korporasi

$H_{1}: \mu_{1} \neq \mu_{2}$, ada perbedaan TVA sebelum dan sesudah aksi korporasi

Pengambilan keputusan, Ho diterima jika tingkat signifikasi lebih besar dari 0.05 (alpha 5\%) atau 0.10 (alpha 10\%), dan sebaliknya jika tingkat signifikasi kurang dari 0,05 (alpha 5\%) atau 0,10 (alpha 10\%) maka H1 diterima.

\section{One Sample t-test}

Alat uji statistic ini digunakan untuk mengetahui ada tidaknya abnormal return disekitar pengumuman aksi korporasi pemecahan saham. Rumusan hipotesisi yang diajukan:

$H_{o}: \mu_{1}=0$, tidak terdapat abnormal return $H_{1}: \mu_{1} \neq 0$, terdapat abnormal return

Pengambilan keputusan, Ho diterima jika tingkat signifikasi lebih besar dari 0.05 (alpha 5\%) atau 0.10 (alpha 10\%), dan sebaliknya jika tingkat signifikasi kurang dari 0,05 (alpha 5\%) atau 0,10 (alpha 10\%) maka $\mathrm{H} 1$ diterima.

\section{HASIL}

\section{Deskripsi Variabel Penelitian}

Variabel utama dalam penelitian ini adalah harga saham dan volume perdagangan saham disekitar corporate action stock split. Pengaruh aksi korporasi pemecahan saham terhdap harga saham emiten terkait dilihat dari ada tidaknya perubahan harga saham dan volume perdagangan saham disekitar hari dan tanggal aksi korporasi stock split. Indikator dari perubahan harga saham tercermin pada ada tidaknya abnormal return dan volume perdagangan saham dari trade volume activity (TVA).

\section{Abnormal return}

Merupakan return yang tidak normal, yaitu kelebihan return diatas atau dibawah return biasanya (expected return). Penelitian ini mengidentifikasinya di periode jendela (window periode) yaitu lima hari setelah cum-date, satu hari bertepatan dengan cum-date dan lima hari sebelum pengumuman aksi korporasi tersebut. Abnormal return dari emiten yang dijadikan sampel disekitar pengumuman stock split sebagaimana Tabel 4.

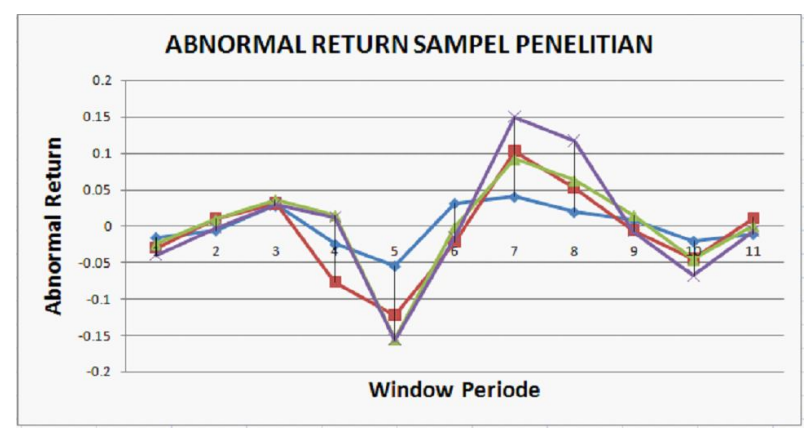

Gambar 1. Visual Grafis

Abnormal Return di Sekitar Periode Jendela Sumber: data yang diolah

Berdasarkan Tabel 4. dapat deskripsikan bahwa abnormal return untuk setiap sampel penelitian pada tiap-tiap periode di periode jendala mengalami perubahan-perubahan, hal ini menunjukkan

Tabel 4. Abnormal Return Di Sekitar Pengumuman Stock Split

\begin{tabular}{cccccccccccc}
\hline No. & $\mathbf{- 5}$ & $\mathbf{- 4}$ & $\mathbf{- 3}$ & $\mathbf{- 2}$ & $\mathbf{- 1}$ & $\mathbf{0}$ & $\mathbf{1}$ & $\mathbf{2}$ & $\mathbf{3}$ & $\mathbf{4}$ & $\mathbf{5}$ \\
\hline BBRI & -.016 & -0.006 & 0.028 & -0.025 & -0.055 & 0.031 & 0.040 & 0.019 & 0.008 & -.021 & -.011 \\
TLKM & -.014 & 0.016 & 0.003 & -0.052 & -0.067 & -.053 & 0.063 & 0.034 & -.013 & -.024 & 0.022 \\
KLBF & 0.005 & -0.001 & 0.005 & 0.092 & -0.033 & 0.021 & -.011 & 0.010 & 0.020 & -.001 & -.011 \\
ASII & -.015 & -0.012 & -.007 & -0.003 & -0.001 & -.015 & 0.057 & 0.053 & -.022 & -.022 & -.008 \\
\hline
\end{tabular}

Sumber: data yang diolah 


\section{Jurnal Keuangan dan Perbankan | KEUANGAN}

Vol. 20, No.3, September 2016: 395- 406

bahwa aksi korporasi berupa pemecahan saham mempengaruhi harga saham terbukti adanya naik dan turunnya abnormal return di periode jendela. Variasi perubahan abnormal return untuk setiap periode jendela dan untuk masing-masing sampel penelitian akan lebih jelas terlihat pada visual grafis sebagaimana Gambar 1.

\section{Trade Volume Activity (TVA)}

TVA merupakan ukuran untuk melihat adanya perubahan volume perdagangan disekitar aksi korporasi yaitu pemecahan saham. Rangkuman Trade Volume Activity (TVA) dari emiten yang dijadikan sampel disekitar pengumuman stock split sebagaimana Tabel 4.2.

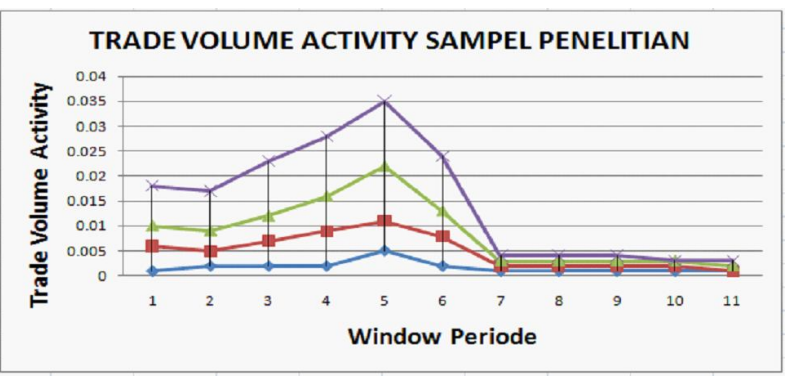

Gambar 4.1.

Visual Grafis Trade Volume Activity

Berdasarkan Tabel 4.2. dapat deskripsikan bahwa TVA untuk setiap sampel penelitian pada tiap-tiap periode di periode jendala sebelum $t=0$ mengalami perubahan-perubahan, hal ini menunjukkan bahwa aksi korporasi berupa pemecahan saham mempengaruhi volume perdagangan saham terbukti adanya naik dan turunnya TVA di periode jendela sebelum $\mathrm{t}=0$. Sedangkan TVA pada periode setelah $\mathrm{t}=0$ relatip stabil. Variasi perubahan Trade Volume Activity untuk setiap periode jendela dan untuk masing-masing sampel penelitian akan lebih jelas terlihat pada visual grafis sebagaimana Gambar 4.2.

\section{PEMBAHASAN}

\section{Pengaruh Stock Split Terhadap Harga Saham}

Penelitian ini focus pada pengaruh aksi korporasi berupa pemecahan saham terhadap harga saham. Pengaruhnya tehadap harga saham akan dilihat dari ada tidaknya abnormal return di sekitar pengumuman stock split, sehingga hipotesis yang diajukan adalah terdapat abnormal return di periode jendela. Berdasarkan analisis statistic dengan metode One Sample t tes, hasil secara empiris menunjukkan terdapat abnormal return baik sebelum pengumuman aksi korporasi maupun pasca cumdate aksi korporasi. Sehari sebelum diumukannya aksi koporasi harga saham justru turun hal ini terbukti adanya abnormal return negatip 3,89\% dan signifikan (tingkat signifikansi 7,5\% < alpha $10 \%)$. Kemudian dua hari pasca cum-date harga saham naik, hal ini terbukti adanya abnormal return positip 2,86\% dan signifikan (tingkat signifikasi 5,5\% < alpha 10\%) dan empat hari pasca cumdate harga saham justru turun, hal ini terbukti adanya abnormal return negatip 1,70\% dan signifikan (tingkat signifikasi 5,3\% < alpha 10\%). Dengan demikian bahwa hipotesis penelitian yang menyatakan bahwa terdapat abnormal return yang signifikan di periode jendala dapat diterima.

Tabel 4.2. Trade Volume Activity (TVA) Sampel Penelitian di Sekitar Pengumuman Stock Split

\begin{tabular}{cccccccccccc}
\hline No. & $\mathbf{- 5}$ & $\mathbf{- 4}$ & $\mathbf{- 3}$ & $\mathbf{- 2}$ & $\mathbf{- 1}$ & $\mathbf{0}$ & $\mathbf{1}$ & $\mathbf{2}$ & $\mathbf{3}$ & $\mathbf{4}$ & $\mathbf{5}$ \\
\hline BBRI & 0.001 & 0.002 & 0.002 & 0.002 & 0.005 & 0.002 & 0.001 & 0.001 & 0.001 & 0.001 & 0.001 \\
TLKM & 0.005 & 0.003 & 0.005 & 0.007 & 0.006 & 0.006 & 0.001 & 0.001 & 0.001 & 0.001 & 0.000 \\
KLBF & 0.004 & 0.004 & 0.005 & 0.007 & 0.011 & 0.005 & 0.001 & 0.001 & 0.001 & 0.001 & 0.001 \\
ASII & 0.008 & 0.008 & 0.011 & 0.012 & 0.013 & 0.011 & 0.001 & 0.001 & 0.001 & 0.000 & 0.001 \\
\hline
\end{tabular}

Sumber: data yang diolah 
Hasil analisis secara empiris membuktikan bahwa pemecahan saham berpengaruh signinifikan terhadap harga saham baik pada periode sebelum pengumuman maupun pada periode pasca cumdate aksi korporasi. Akan tetapi reaksi pasar justru bervariasi terhadap aksi ini terbukti pada periodeperiode tersebut terdapat abnormal return baik positip maupun negatip. Tepatnya sehari sebelum pengumuman terdapat abnormal return negatip dan dua hari pasca cum-date terdapat abnormal return positip.

Abnormal return negatip sebelum pengumuman mengindikasikan bahwa aksi korporasi ini tidak diketahui oleh investor, keputusan investor tidak memasukkan informasi terkait dengan pemecahan saham. Sehingga keputusan mereka diprediksi berdasarkan informasi pada umumnya yang ada dipasar saat itu, yaitu berdasarkan factor fundamental dan teknikal. Aksi korporasi ini dapat dimaknai tidak bocor sebelum diumumkan kepublik terbukti tidak ada abnormal return positip sebelum periode tersebut, tetapi justru abnormal return negatip. Hasil empiris ini mendukung Kurniawati (2013).

Berbeda halnya reaksi pasar atas aksi korporasi pasca eksekusi yaitu terdapat abnormal return positip. Harga saham naik secara signifikan pasca pemecahan saham, investor bereaksi secara positip. Hasil empiris ini mendukung penelitian sebelumnya sebagaimana Cakrabroty (2012), tetapi bertentangan dengan hasil penelitian Fama, Fisher, Jensen, and Roll (1969), Mishra (2006) dan Pooja (2013). Minimal terdapat dua alasan mengapa pemecahan saham bisa meningkatkan harga saham, pertama investor menginterprestasikan kinerja emiten yang melakukan aksi meningkat atau terdapat potensi kenaikan kinerja di masa yang akan datang. Terkait dengan pemecahan saham mengapa dilakukan karena kalau harga saham sadah mahal maka meskipun kinerja membaik harga saham tidak bisa naik lagi secara signifikan, oleh karena itu emiten melakukan pemecahan saham. Harga saham yang mahal mengakibatkan tidak banyak investor yang tertarik untuk membeli saham tersebut meskipun emiten mempunyai kinerja yang semakin baik. Sebagai contoh sebelum emiten saham Multi Bintang (MLBI) melakukan pemecahan saham harga saham perlembar sangat mahal untuk ukuran saham-saham di Bursa Efek Indonesia (BEI) Rp.1500.000; per-lembar saham. Pada harga tersebut tentunya sangat mahal bagi investor level menengah kebawah untuk membeli saham tersebut, karena pembelian unit saham minimal di BEI adalah 1 lot maka investor minimal harus mengeluarkan dana investasi sebesar 150 juta Rupiah dan buakn merupakan jumlah dana yang kecil bagi investor menengah kebawah. Oleh karena itu harga saham relatip stagnan meskipun kinerja emiten mengalami perbaikan-perbaikan.

Alasan kedua mengapa harga saham naik (abnormal return positip) pasca eksekusi pemecahan saham adalah harga saham menjadi semakin murah dimata investor. Semakin murahnya harga saham pasca aksi berakibat investor yang pada mulanya tidak mampu membeli saham tersebut, pasca aksi investor menjadi mampu beli sehingga semakin banyak investor yang tertarik pada saham tersebut. Sesuai dengan hukum supply demand jika sisi demand mengalami kenaikan maka harga akan naik. Sebagaimana halnya emiten yang melakukan aksi korporasi, diprediksi sisi demand meningkat selanjutnya mendorong harga saham naik dan abnormal return positip signifikan.

\section{Pengaruh Stock Split Terhadap Volume Perdagangan Saham}

Penelitian ini selain focus pada pengaruh aksi korporasi berupa pemecahan saham terhadap harga saham juga pada volume perdagangan saham. Pengaruhnya tehadap volume perdagangan saham akan dilihat dari ada tidaknya perbedaan antara Trade Volume Activity (TVA) sebelum dan sesudah aksi korporasi pemecahan saham. Berdasarkan analisis statistic dengan metode paired Sample $t$ tes, hasil empiris dapat dinterprestasikan 


\section{Jurnal Keuangan dan Perbankan | KEUANGAN}

Vol. 20, No.3, September 2016: 395- 406

bahwa TVA pasca aksi korporasi justru turun, dari $0,6 \%$ sebelum aksi koporasi menjadi $0,1 \%$ pasca aksi koporasi. dan signifikan dengan tingkat signifikasi 0,000 (tingkat signifikasi < 5\%). Sehingga hipotesis penelitian bahwa terdapat perbedaan TVA yang signifikan sebelum dan sesudah aksi korporasi pemecahan saham diterima.

Secara empiris terbukti volume perdagangan saham justru menurun secara signifikan paska eksekusi aksi pemecahan saham. Terdapat beberapa logika berpikir positip dari investor dan hal ini memperkuat temuan empiris pertama yaitu harga saham naik pasca aksi. Investor berkeyakinan bahwa emiten pelaku aksi mempunyai kinerja yang semakin baik atau minimal ada potensi kenaikan kinerja. Oleh karena itu pasca aksi yang banyak terjadi adalah aksi beli, sisi demand naik mengakibatkan naiknya harga saham (memperkuat temuan empiris pertama yaitu abnormal return positip signifikan) sedangkan aksi jual menurun sehingga TVA menurun sesuai temuan empiris kedua. Menurunnya aksi jual (perlu penelitian lebih lanjut) diakibatkan investor yang tidak ingin menjual sahamnya saat ini mereka ingin meng-hold saham tersebut dalam periode yang lebih lama lagi dengan harapan akan memperoleh gain yang lebih besar lagi atau mereka ingin mendapat dividen yang besar lagi karena mereka yakin bahwa kinerja emiten pelaku aksi mempunyai kinerja yang semakin baik.

Analisis ini juga sebagai sinyal kurang sempurnanya variable TVA, yang mana hanya mengukur jumlah volume perdagangan dimana didalamnya mengandung volume penjualan dan pembelian saham. Sehingga jika terjadi TVA yang menurun sebagaimana ditemukan dalam penelitian ini, tidak diketahui yang turun adalah penjualan saham atau pembelian sahamnya. Naik dan turunnya dua aspek tersebut mempunyai implikasi besar pada emiten-emiten yang malakukan aksi korporasi. Sesuai temuan pertama terkait adanya abnormal return positip pasca aksi maka diprediksi dalam TVA yang menurun tersebut terkandung data kenaikan volume perdagangan saham dalam arti kanaikan volume pembelian saham sehingga mengakibatkan naiknya harga saham.

Analisis lain mengapa TVA justru menurun pasca aksi korporasi adalah periode pengamatan (window periode) yang terlalu pendek (penelitian ini menggunakan 11 hari sebelum dan sesudah) sehingga banyak investor banyak melakukan aksi beli dan sedikit yang melakukan aksi jual sehingga secara keseluruhan TVA menurun. Investor akan menjual saham-sahamnya jika sudah memperoleh gain yang signifikan dalam waktu yang relatip pendek belum bisa tercapai. Pada akhirnya hasil penelitian ini bertentangan dengan rabroty (2012), Fama, Fisher, Jensen, and Roll (1969), Mishra (2006) dan Pooja (2013).

Bagi investor yang akan memutuskan aksi beli atau jual saham di pasar modal sudah selayaknya memperhatikan aksi korporasi emiten dimana sahamnya akan dibeli. Sesuai hasil temuan empiris dalam penelitian ini bahwa aksi korporasi pemecahan saham berdampak pada kenaikan harga saham yang dimaknai kinerja emiten mengalami kenaikan atau minimal adanya potensi kenaikan kinerja emiten. Oleh karena itu direkomendasikan untuk membeli saham-saham dari emiten yang malakukan aksi korporasi pemecahan saham.

Menurunnya volume perdagangan saham (TVA) jangan diartikan saham semakin tidak diminati oleh investor, tetapi justru sebaliknya diprediksi pasca akasi korporasi aksi jual saham turun dan aksi beli saham naik karena investor berharap mendapatkan gain atau dividen yang lebih besar dari emiten-emiten yang melakukan aksi korporasi pemecahan saham pada periode pasca eksekusi aksi korporasi tersebut.

\section{KESIMPULAN}

1. Informasi aksi korporasi emiten yang tergabung dalam Indeks LQ-45 tidak bocor kepu- 
blik sebelum diumumkan terbutki secara empiris tidak terdapat abnormal return positip pada periode sebelum pengumuman aksi korporasi pemecahan saham.

2. Harga saham naik pasca aksi korporasi pemecahan saham, terbukti secara empiris terdapat abnormal return positip signifikan. Temuan ini dimaknai bahwa investor berkeyakinan kinerja emiten pelaku eksi mempunyai kinerja yang baik atau minimal mempunyai potensi kinerja akan membaik sehingga mereka malakukan aksi pembelian saham sehingga harga saham naik.

3. Volume perdagangan saham (TVA) pasca aksi korporasi menurun secara signifikan, hal ini bukan berarti bertentangan dengan kesimpulan sebelumnya. TVA mencatat semua transaksi saham baik aksi beli maupun jual, sehingga dapat diinterprestasikan menurunnya TVA disebabkan aksi jual saham terkait aksi korporasi pemecahan saham turun, sedangkan aksi beli semakin meningkat sehingga harga saham naik dan terdapat abnormal return positip signifikan sebagaimana kesimpulan sebelumnya.

\section{SARAN}

1. Agar hasil penelitian lebih komprehensip maka periode jendela bisa lebih diperpanjang misalnya 61 hari, sehingga investor sudah mempunyai periode yang cukup untuk memahami dampak aksi korporasi emiten.

2. Perlu penelitian lebih mendalam terkait dengan variable volume perdagangan saham (TVA) sisi mana yang mengalami kenaikan atau penurunan, apakah pada sisi penjualan saham atau sisi pembelian saham akibat aksi korporasi pemecahan saham.

\section{DAFTAR PUSTAKA}

Baker, Phillips \& Powell (1995). Financial Practice and Education, The Stock Distribution Puzzle: A Synthesis Of The Literature, Spring/Summer.
Bechmann and Raaballe (2007). Journal of Business Finance $\mathcal{E}$ Accounting, 34(3) \& (4), 574-604, April/May 2007, 0306-686Xdoi: 10.1111/j.14685957.2007.02041.x, The Differences Between Stock Splits and Stock Dividends: Evidence on the Retained Earnings Hypothesis, USA.

Chhavi iVIehta, Surendra S. Yadav, and P.K. Jain (2011). Managerial Motives for Stock Splits;Survey Based Evidence from India. Journal Of Applied FinanceNo. 1.

Deborah A. Ford, Hoang H. Nguyen, and Van T. Nguyen (2012). Analyst coverage and market reaction around stock split announcements, Applied Financial Economics, 2012, 22, 135-145.

Fama, Eugene F,, Lawrence Fisher, Michael C. Jensen, and Richard Roll (1969). "The Adjustment of Stock Prices to New Information, International Economic Review 10:1 (February), 1-21.

Hwang et al. (2012). International Atlantic Economic Society, Do Reverse Stock Splits Benefit Long-term Shareholders?, Springer, DOI 10.1007/s11294012-9370-3.

Jones Charles P. (2007). Investments, John Wiley \& Sons(Asia) Pte. Ltd.

Kurniawati, Indah. 2003. Analisis Kandungan Informasi Stock Split dan Likuiditas Saham: Studi Empiris pada Non-synchronus Trading. Jurnal Riset Akuntansi Indonesia. Vol. 6. No. 3. P. 264-275

Lakonishok, Josef and Baruch Lev, 1987, “Stock Splits and Stock Dividends: Why, Who, and When," Journal of Finance 42:4(September), 913-932.

Madhumita Chakraborty (2012). The Equity Market around the Ex-Split Date: Evidence from IndiaVikalpa Volume 37 • NO 1 • January March.

Mishra (2006). International Journal of Theoretical and Applied Finance Vol. 10, No. 2 (2007) 251271c,World Scientific Publishing Company.

Mayank, Joshipura (2009). Indian Journal Of Finance, Price and liquidity effects of stock split: An Empirical evidence from Indian stock market, Volume 3, Issue 10, October 2009.

Nelson Maina Waweru and John Mwendwa (2012). Stock Splits And Their Effect On Share Prices: A Study Of Firms Listed On The Nairobi Stock Exchange 


\section{Jurnal Keuangan dan Perbankan | KEUANGAN}

Vol. 20, No.3, September 2016: 395- 406

(NSE), Academy of Accounting and Financial Studies Journal, Volume 16, Number 2.

Pooja (2013). Stock Split Announcement and Liquidity Effect: Evidence from India,Vilakshan, XIMB Journal Vol.10 (1) ; March.
Weihrich and Koontz (1990). Essentials of Management, Fifth Edition, McGraw-Hill Publishing Company, Singapore.

Yan, Junbo (2012). Journal of Applied Finance, Stock Split Decisions: A Synthesis of Theory and Evidence, United Stated. 